\title{
Pendampingan Pengrajin Pot Antik Sido Mulyo dengan Marketplace dalam Meningkatkan Pemasaran pada Era Pandemi Covid-19
}

\author{
${ }^{1}$ Nadia Annisa Maori*, ${ }^{2}$ Eka Setya Budi, ${ }^{1}$ Bambang Siswanto, \\ ${ }^{2}$ Naila Khusnia Sari, ${ }^{3}$ Noor Laily Isnaini \\ ${ }^{1}$ Prodi Teknik Informatika, Fakultas Sains dan Teknologi, UNISNU, Jepara, Indonesia \\ ${ }^{2}$ Prodi Pendidikan Agama Islam, Fakultas Tarbiyah dan Ilmu Keguruan, UNISNU, Jepara, Indonesia \\ ${ }^{3}$ Prodi Manajemen, Fakultas Ekonomi dan Bisnis, UNISNU, Jepara, Indonesia \\ *Corresponding Author: \\ E-mail: nadia@unisnu.ac.id
}

Received:
1 January 2021

Revised:

15 April 2021
Accepted:

15 May 2021
Published:

31 May 2021

\begin{abstract}
Abstrak
Media pemasaran yang tepat, sangat mendukung keberhasilan suatu usaha baik dari usaha kecil sampai besar. Oleh karenanya, pemilihan dan penggunaan media pemasaran harus disesuaikan dengan kondisi pasar saat ini. Memasarkan pot antik dengan cara menjajakan pot antik di pinggir jalan raya menunggu calon pembeli. Hal ini dirasa kurang efektif seiring dengan kemajuan zaman yang serba online dan pada situasi pandemi Covid-19 yang terkesan kurang inovatif. Hal ini menjadikan pemasaran produk pot antik tersendat dan solusi yang ditawarkan pada program pengabdian kepada masyarakat berbasis mitra ini adalah pemanfaatan marketplace (Shopee) bagi mitra Pot Antik Sido Mulyo sebagai media pemasaran penjualan Pot antik. Kegiatan ini diharapkan akan membentuk proses pemasaran penjualan yang efektif antara penjual dan pembeli, sehingga proses pemasaran akan lebih cepat dan mudah. Permasalahan yang dihadapi mitra Pot Antik Sido Mulyo yaitu (1) hasil penjualan Pot Antik menurun seiring pembatasan sosial yang ditetapkan pemerintah. (2) Masih terbatasnya pengetahuan pengrajin tentang media pemasaran yang tepat dalam memasarkan produk pot antik sehingga masih mempertahankan cara pemasaran konvensional. Marketplace adalah suatu tempat tertentu dimana pasar atau kegiatan jual-beli antara pemilik toko dan konsumen berlangsung secara publik. Sedangkan Shopee adalah salah satu aplikasi yang bergerak dalam bidang jual beli, pertama kali didirikan di Indonesia pada Juni 2015. Dengan adanya marketplace Shopee bagi pengrajin Pot antik Sido Mulyo diharapkan hasil pemasaran penjualan Pot Antik dapat tercapai secara maksimal dengan teknologi yang semakin memudahkan.
\end{abstract}

Kata kunci: Pemasaran; marketplace; Shopee; pot antik

\section{Abstract}

The right marketing media really supports the success of a business, from small to large businesses. Therefore, the selection and use of marketing media must be adapted to current market conditions. Marketing antique pots by selling antique pots on the side of the highway waiting for potential buyers. This is deemed ineffective in line with the progress of the online era and in the situation of the Covid-19 pandemic which seems less innovative. This makes marketing of antique pot products stagnant and the solution offered in this partner-based community service program is the use of a 
marketplace (Shopee) for Sido Mulyo's Antique Pot partners as a marketing medium for selling antique pots. This activity is expected to form an effective sales marketing process between sellers and buyers, so that the marketing process will be faster and easier. The problems faced by Sido Mulyo's Antique Pot partners are (1) sales of antique pots have decreased in line with social restrictions set by the government. (2) There is still limited knowledge of craftsmen about the right marketing media in marketing antique pot products so that they still maintain conventional marketing methods. Marketplace is a certain place where the market or buying and selling activities between shop owners and consumers takes place in public. Meanwhile, Shopee is an application that is engaged in buying and selling, first established in Indonesia in June 2015. With the Shopee marketplace for Sido Mulyo antique pot craftsmen, it is hoped that the marketing results of antique pot sales can be maximally achieved with technology that makes it easier.

Keywords: Marketing;marketplace; Shopee; antique pot

\section{PENDAHULUAN}

Terdapat beberapa masyarakat Jepara yang bergerak di usaha rumahan atau UMKM di Desa Bapangan salah satunya adalah Pot Antik Sido Mulyo yang berada di Desa Bapangan RT 01 RW 05 Kecamatan Jepara Kabupaten Jepara. Pot Antik Sido Mulyo berjarak kurang lebih 3 KM dari pusat kota Jepara. Usaha pot antik ini berdiri pada tahun 2018 dan beroperasi hingga sekarang yaitu tahun 2021. Pot antik ini dipimpin dan dikelola oleh Bapak Ponco Manitis Retno Asmoro sendiri bersama dengan istrinya dan belum memiliki karyawan. Awal mula terbentuknya usaha ini bermula dari keinginan Bapak Ponco yang tergerak untuk memanfaatkan dan mengelola barang limbah kain dan karung goni yang banyak ditemukan di lingkungan sekitar untuk menjadikan barang yang memiliki nilai jual sekaligus untuk mengangkat perekonomian masyarakat sekitar.

UMKM merupakan usaha produktif untuk dikembangkan bagi mendukung perkembangan ekonomi secara makro dan mikro di Indonesia dan mempengaruhi sektor-sektor yang lain bisa berkembang (Suci, 2017). Permasalahan yang dihadapi mitra yaitu keterbatasan pengetahuan mengenai teknologi dan teknik pemasaran. Dengan permasalahan yang ada mengakibatkan tersendatnya kegiatan usaha pot antik ini. Ditambah usaha pot antic ini memiliki permasalahan utama tentang pemasaran. Seiring dengan pandemi Covid-19 Dimana usaha pot antik ini masih mempertahankan model pemasaran konvensional dengan menjajakkan pot antic ini di trotoar dengan harapan banyak calon pembeli yang melihat dan membeli tetapi pemberlakuan peraturan pembatasan sosial oleh pemerintah mengakibatkan para calon pembeli enggan berhenti dan melihat produk pot karena takut tertular virus Covid-19 sehingga mengakibatkan sepinya minat pembeli dan penjualan produksi pot antik karena kebijakan tersebut. 


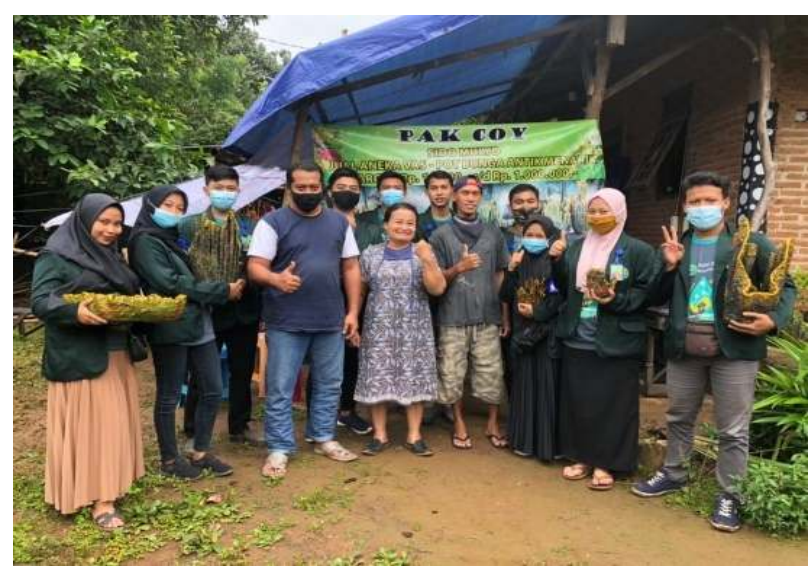

Gambar 1. Deskripsi Tempat Produksi Pot Antik Sido Mulyo

Berdasarkan hasil observasi yang telah observer lakukan di Pengrajin Pot Antik Sido Mulyo. Model pemasaran konvensional yang dilalukan belum menampakkan hasil yang optimal dan ditambah lagi pada era pandemi Covid-19 semakin menyulitkan pemasaran serta penjualan produk pot antik ini. Aspek - aspek permasalahan proses pemasaran penjualan Pot Antik sido Mulyo sebagai berikut: (1) Masih terbatasnya pengetahuan pengrajin tentang pemasaran penjualan (2) Sebagian besar pembeli tertarik pada media penjualan melalui online karena dianggap praktis (3) Model pemasaran yang digunakan pengrajin masih konvensional (4) Sarana dan prasaranany amasih belum lengkap (5) Tidak adanya kreativitas dan inovasi pemasaran penjualan.

Permasalahan prioritas yang dihadapi mitra Pot Antik Sido Mulyo adalah pemasaran penjualan yang tersendat karena pembatasan sosial oleh pemerintah pada saat pandemi Covid19. Pemerintah Indonesia masih hanya melakukan penanganan berupa pembatasan sosial saja atau (social distancing).(Wahidah, 2020). Pengrajin belum menemukan media yang tepat yang digunakan untuk media pengganti pemasaran konvensional dengan cara menjajakkan ditrotoar pinggir jalan. Pengrajin cenderung bersifat pragmatis (rejeki wes ono seng ngatur): Rejeki sudah ada yang mengatur, pengrajin hanya mengandalakan pemasaran penjualan yang sudah berjalan dari mulut kemulut saja. Hal ini terjadi baik di Pot Antik sido Mulyo.

Menyadari permasalahan yang dihadapi oleh pengrajin pot antik Sido Mulyo yang cukup kompleks, maka solusi yang ditawarkan adalah Pendampingan Pengrajin Pot Antik Sido Mulyo dengan Marketplace dalam Meningkatkan Pemasaran di Era Pandemi Covid-19. Dengan adanya pendampingan pembuatan akun marketplace (Shopee) tersebut maka diharapkan produk pot antik mampu berkembang dan dapat dijadikan sebagai produk unggulan daerah Kabupaten Jepara.

\section{METODE}

Pelatihan Pendampingan Pengrajin Pot Antik Sido Mulyo dengan MarketPlace dalam Meningkatkan Pemasaran di Era Pandemi Covid-19 yang dilaksanakan pada hari Selasa 23 Februari 2021. Perlu diadakannya pelatihan kepada pengrajin masih kurangnya pengetahuan dalam bidang teknologi khusunya dalam pemasaran secara online melalui marketplace. Saat ini pengrajin tersebut belum memiliki karyawan dan pemasaran masih bersifat konvensional. Adapun kegiatan yang dilakukan sebagai berikut.

Pada tahap pelaksanaan dibagi menjadi 3 tahapan yaitu tahap pertama, pengabdi memberikan materi dan gambaran tentang media Marketplace terutama pada shopee kepada para pengrajin pot antik. Tahap kedua, pengimplementasian pembuatan akun Shopee dengan memasukkan semua data toko dan produk pot antik. Dan tahap ketiga pengujian pemasaran penjualan serta melakukan evaluasi terhadap media pemasaran penjualan Shopee kepada mitra. Gambaran mengenai proses pembuatan media pemasaran dimulai dari pembuatan 1) analisis 
kebutuhan konsumen 2) pemilihan media pemasaran yang tepat dan disesuaikan dengan kemampuan dan kebutuhan mitra seperti cara penggunaan yang mudah dipahami 3) Pembuatan akun media pemasaran 4) ProsesP emasaran. Penjelasan poin-poin yang mencerminkan urutan langkah-langkah tersebut dijelaskan dalam bagan berikut.

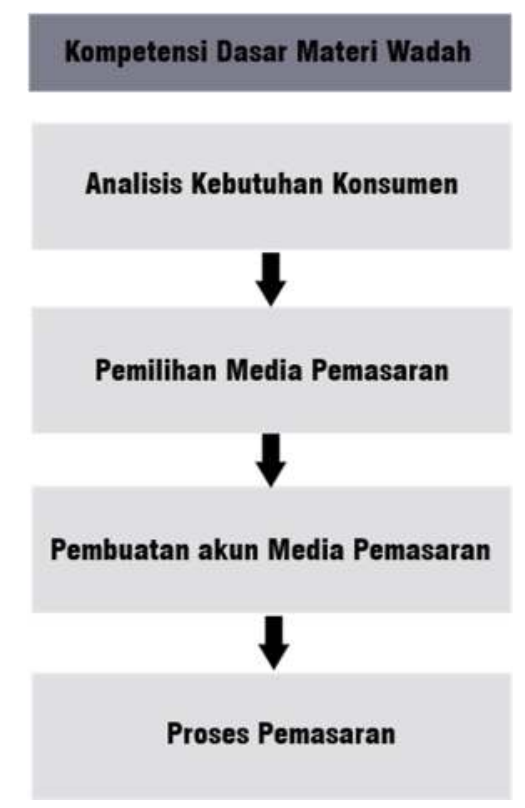

Gambar 2. Bagan alur PKM pembuatan akun media pemasaran.

Penjelasan mengenai bagan tersebut diuraikan dalam beberapa tahapan yang telah disampaikan pada bagian 1 sampai dengan 4. Tahapan dijelaskan secara rinci sebagai wujud aktualisasi proses pembuatan media dengan proses sebenarnya (Sugiyono,2009). Tahap persiapan yaitu tahap menyiapkan syarat-syarat yang akan digunakan untuk pembuatan akun Shopee . Adapun syarat-syarat yang digunakan adalah: Handphone, jaringan internet, data toko yang akan dibuat, rekening tabungan bank, foto-foto produk pot antik, harga dan spesifikasi produk. Tahap persiapan ini juga dipersiapkan agar pengrajin pot antik sido mulyo siap mengikuti pembuatan media pemasaran online untuk memasarkan penjualan melalui marketplace Shopee. Proses pengembangan pemasaran melalui media marketplace Shopee bertujuan untuk mengenalkan produk pot antik dikalayak luas tanpa mengenal jarak dan waktu. Berikut Urutan Pembuatan akun Shopee Pot antik Sido Mulyo sebagai berikut : (1) Register \& Login (2)Pengaturan Profil, Alamat Toko dan Rekening Bank (3) Pengaturan Produk Barang (4) Pengaturan Voucher dan Promosi (5) Pengaturan Ongkir dan Pengiriman. 


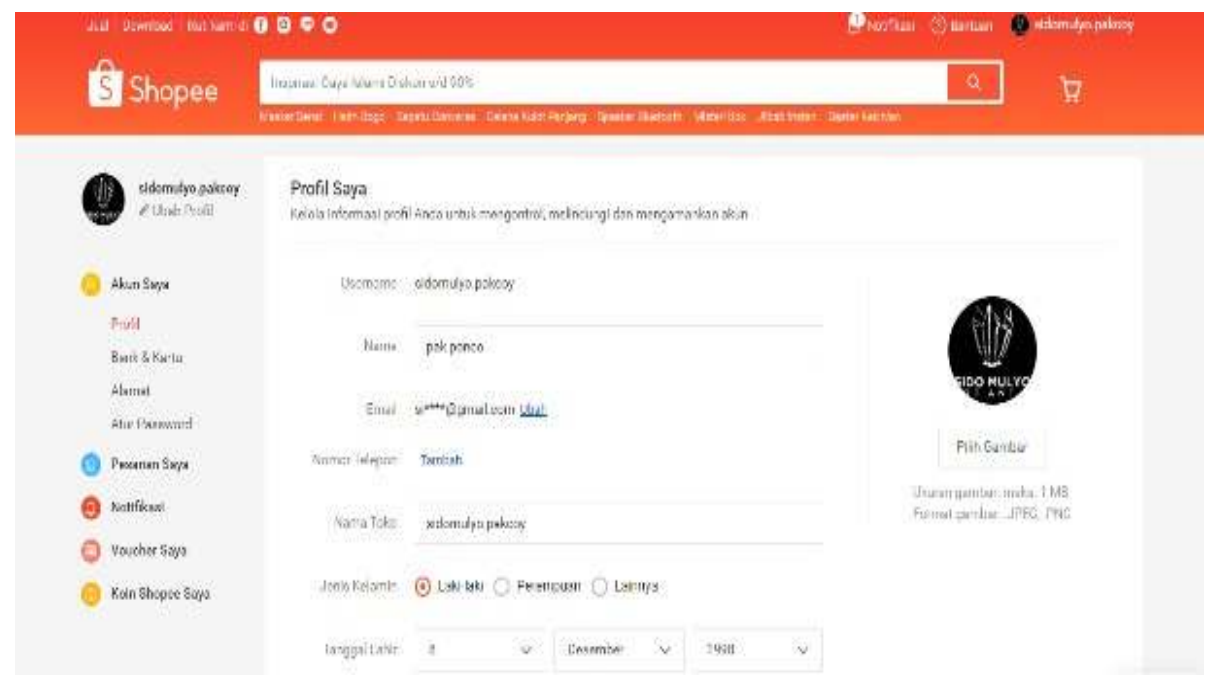

Gambar 3. Tampilan akun Shopee Pot Antik Sido Mulyo.

\section{HASIL DAN PEMBAHASAN}

Dengan adanya kegiatan pengabdian masyarakat ini dapat memberikan solusi terhadap permasalahan yang ada dengan melakukan kegiatan pendampingan dan pelatihan pemasaran dengan media market place (Shopee) terhadap usaha Pot Antik Sido Mulyo. Mitra membuat pot ini dengan memanfaatkan dan mengelola barang limbah kain dan karung goni yang banyak ditemukan di lingkungan sekitar untuk menjadikan barang yang memiliki nilai jual sekaligus untuk mengangkat perekonomian masyarakat sekitar. Dan dilakukannya penambahkan varian baru pada produk ini. Hal ini dilakukan untuk memperluas pasar yang mereka bidik dan menguatkan merek tersebut dikalangan masyarakat luas (Firmansyah, 2019).

Pemasaran merupakan sistem keseluruhan dari berbagai kegiatan bisnis/usaha yang ditunjukkan untuk merencanakan, menentukan harga barang/jasa, mempromosikan, mendristribusikan dan memuaskan konsumen (Rahmawati, 2016). Marketplace merupakan model bisnis baru yang berkembang seiring pesatnya perkembangan infrastruktur teknologi informasi. Marketplace ini dirancang untuk meminimalisir proses bisnis yang kompleks sehingga tercipta efisiensi dan efektivitas (Yustiani \& Yunianto, 2017).

Dengan adanya Marketplace tersebut setiap orang dapat melakukan aktivitas jual beli dengan mudah, cepat dan murah karena tidak ada batas ruang, jarak dan waktu. Secara konvensional pasar memiliki beberapa peran diantaranya menfasilitasi transaksi dan menyediakan infrastruktur. Merupakan model bisnis baru yang berkembang seiring pesatnya perkembangan media sosial yang semakin maju. Media Sosial adalah produk dari Tekhnologi informasi memberikan manfaat optimal bagi pelaku usaha (Rosmadi, 2021). Marketplace ini dirancang untuk meminimalisir proses bisnis yang kompleks sehingga tercipta efisiensi dan efektivitas.

Shopee adalah situs elektronik Singapura di bawah naungan SEA Group yang didirikan pada 2009 oleh Forrest Li. Shopee pertamakali diluncurkan di Singapura pada tahun 2015, dan telah meluas diberbagai mancanegara. Shopee sendiri dipimpin oleh Chris Feng, mantan karyawan Rocket Internet yang pernah memimpin Zalora dan Lazada. Sejarah Shopee diIndonesia dimulai pada bulan Desem bertahun 2015. Prestasi marketplace ini adalah keberhasilan promosi yang dalam waktu singkat, pengguna shopee tidak kalah banyak dari para pesaingnya. Shopee memudahkan para penjual serta pembeli dalam berinteraksi melalui fitur live chatnya. Dan Shopee berhasil mendapatkan perhatian konsumen dan kepedulian di mata penggunanya khususnya masyarakat di Indonesia (Suswanto \& Setiawati, 2020). 


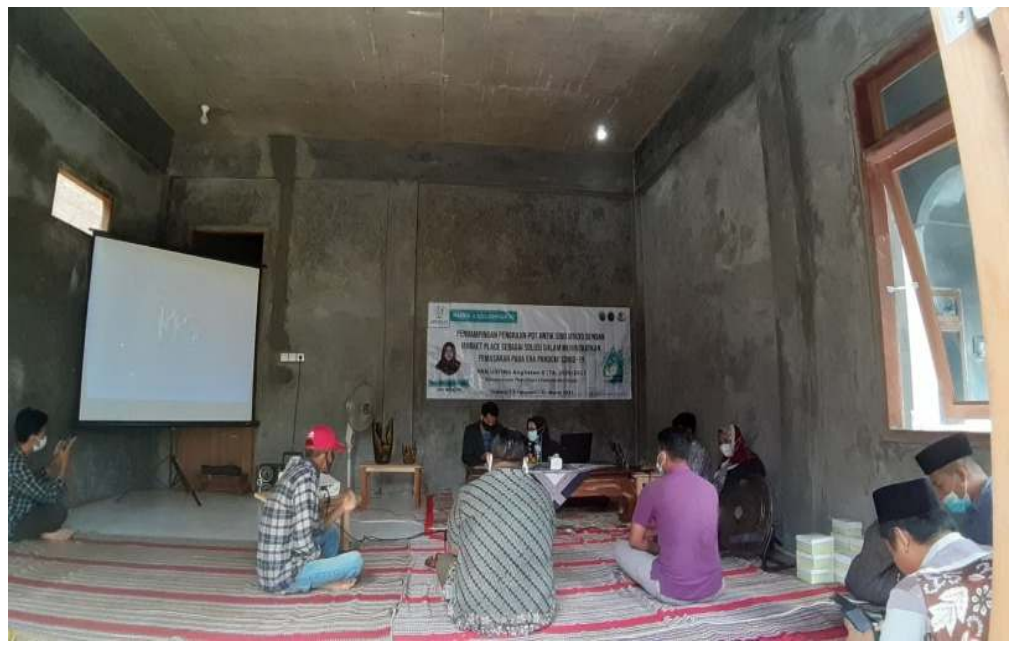

Gambar 4. Pendampingan pembuatan akun marketplace (Shopee) Pot Antik Sido Mulya.

Hal penting yang perlu diketahui dalam berjualan di Shopee agar banyak orderan harus memliki strategi yang tepat. Berikut beberapa strategi berjualan di Shopee sebagai berikut :

\section{Strategi Mendapatkan Orderan pertama di Shopee}

(1)Daftar Gratis Ongkir dengan cara Masuk ke Aplikasi Shopee di handphoneAnda, pilih menu Gratis Ongkir Xtra diHalaman Utama >Pilih menu 'Semua Gratis Ongkir', scroll sampai ke bawah dan klik 'Daftar Sekarang'. Lengkapi Pendaftarannya dan pengajuan Gratis Ongkir akan diproses. (2) Harga Yang Kompetitif pastikan harga produk yang ditawarkan Shopee Seller sudah kompetitif dan bisa bersaing dengan harga produk lainnya. Ketahui harga pasaran produk, agar harga yang ditetapkan Shopee Seller tidak kemahalan atau kemurahan. (3) Informasi Produk Yang Akurat: (a) Unggah Foto yang Relevan \& Berkualitas Tinggi yaitu resolusi foto yang baik dan latar belakang warna solid (sebaiknya putih) (b) Beri Nama Produk yang Terstruktur yaitu Nama Produk Terstruktur $=$ Merek + Model Produk + Spesifikasi + Ukuran (c) Tulis Deskripsi yang Informatif yaitu jelaskan spesifikasi, kegunaan dan garansi produk dengan kemasan kata yang menarik (d) Pilih Kategori yang Tepat yaitu memilih kategori yang sesuai dengan produk yang diupload (e) Isi Atribut yang Sesuai yaitu maksimum 20 variasi untuk setiap level dan ada 2 level variasi (4) Naikkan Produk Fitur 'NaikkanProduk' di Shopee dapat membuat produk Shopee Seller tampil dihasil pencarian teratas, dan meningkatkan kesempatan produk akan dilihat oleh pembeli. Fitur ini dapat digunakan hingga 5 produk, selama 4 jam sekali. Untuk menaikkan produk melalui aplikasi, klikSaya $>$ TokoSaya $>$ scroll kebawah $>$ pilih produk $>$ klik Naikkan Produk. (5) Perbanyak Variasi Produk perbanyak variasi produk dengan berbagai macam warna dan ukuran. Semakin banyak dan lengkap variasi produk, akan lebih banyak kesempatan untuk mendapatkan pembeli. (6) Buat Voucher Toko Gunakan fitur 'VoucherToko' untuk memberikan promosi yang menarik. Klik bagian 'Promosi Saya', lalu pilih 'Voucher Toko Saya' dan klik 'Buat Voucher Baru' untuk membuat voucher toko via Seller Centre. KlikSaya $>$ Toko Saya $>$ Promosi Saya $>$ Voucher untuk membuat voucher took via aplikasi. (7) Gunakan Media Sosial Manfaatkan Media Sosial untuk mempromosikan Tokomu. Tampilkan tautan (link) Toko Shopee-mu dibio Media Sosial, agar pembeli dapat lebih mudah mengakses Toko Shopee-mu. 


\section{Strategi Fitur Promosi di Shopee}

(1) Membuat promosi melalui aplikasi Shopee Seller dapat membuat Voucher Toko Saya melalui Aplikasi Klik menu Saya $>$ Toko Saya $>$ PromosiSaya $>$ Voucher. (2) Membuat Promosi Melalui Seller Centre dapat menggunakan fitur promosi Shopee untuk meningkat kankunjungan toko dan meningkatkan jumlah pesanan. Akses Fitur Promosi Shopee melalui Seller Centre and klik "Promosi Saya".

\section{Strategi Menaikkan Iklan di Shopee}

Fitur untuk memasang iklan produk berbayar di dalam aplikasi dan website Shopee agar produk dapat dilihat oleh lebih banyak pengguna Shopee. Shopee Seller hanya perlu membayar ketika Pembeli klik iklanmu. Dapatkan lebih banyak Pembeli \& tingkatkan penjualan dengan Iklanku. Shopee Seller dapat mulai beriklan dengan 2 tipe Iklan, sebagai berikut: (1) Iklan Kata Kunci tempatkan produk mu diposisi teratas halaman hasil pencarian. (2)Iklan Produk Serupa jangkau pembeli yang tertarik dengan produk mudah halaman kategori dan halaman produk.

\section{Pemasaran Melalui Marketplace (Shopee)}

Tim pengabdi telah membangun pondasi berupa Markerplace (Shopee) sebelum berbagai media dimanfaatka nuntuk menunjang penjualan. Pondasi yang dimaksud adalah tim pengabdi membuat akun marketplace (Shopee) yang akan dijadikan sebagai promosi online. Selain itu, marketplace (Shopee) ini juga kita jadikan sebagai pusat tempat rujukan ketika kita hendak menyebar promosi online lewat sosial media.

\section{Penguatan Media Pemasaran}

Pada tahapan penguatan media pemasaran tim melakukan berbagai upaya dalam meningkatkan penjualan melalui online marketing diantaranya mendorong mitra untuk membangun media sosial guna mempermudah upaya mencari pelanggan baru. Media social yang telah digunakan mitra adalah Instagram dan Facebook. Instagram menjadi piihan utama karena perubahan budaya masyarakat dalam menggunakan sosial media. Dengan Instagram memudahkan penjual mengenalkan produk-produk melalui foto-foto produk yang menarik.

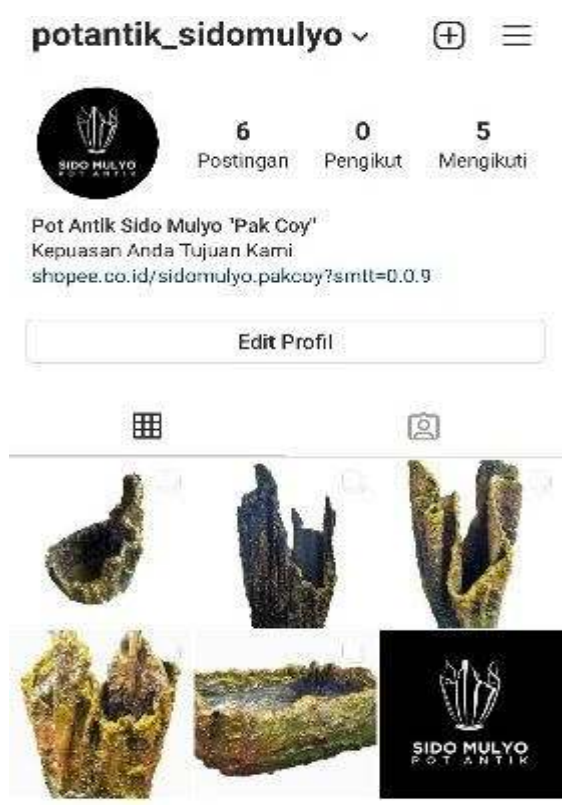

Gambar 5. Tampilan akun Instagram Pot Antik Sido Mulyo. 


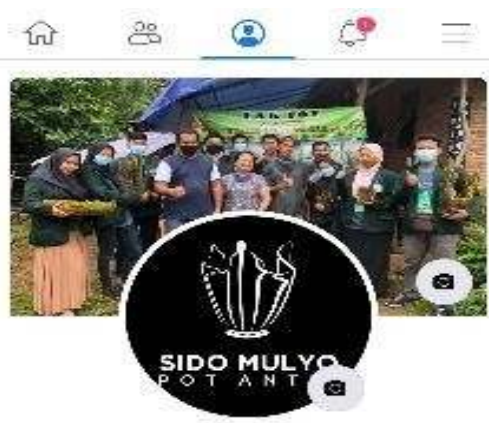

\section{Pot Mulyo}

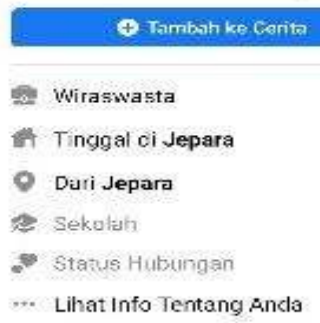

Edit Detall Publik

Gambar 6. Tampilan akun Facebook Pot Antik Sido Mulyo.

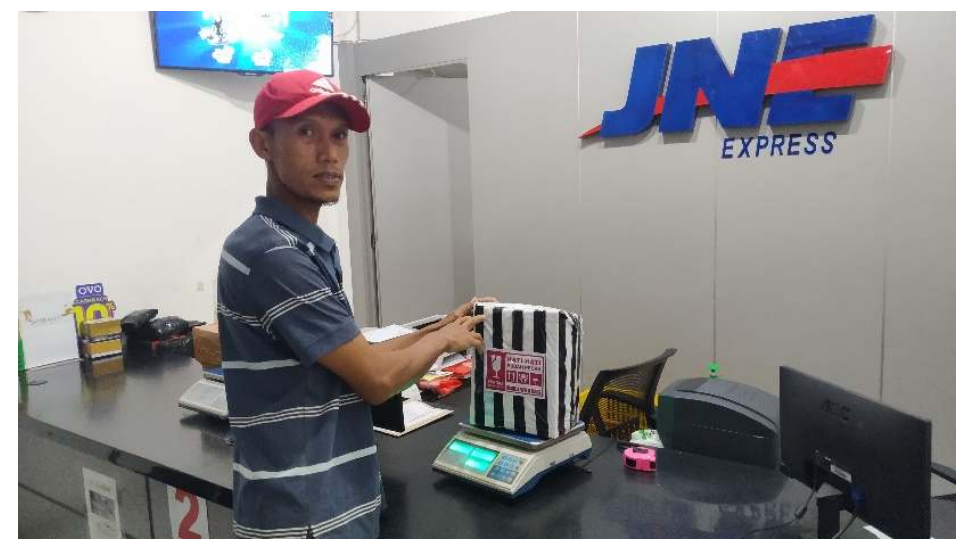

Gambar 7. Proses pengiriman pot antik kepada pembeli.

\section{KESIMPULAN}

Berdasarkan hasil kegiatan dan pembahasan diatas, pengabdi menyimpulkan bahwa program Pendampingan Pengrajin Pot Antik Sido Mulyo dengan Marketplace dalam Meningkatkan Pemasaran di Era Pandemi Covid-19 adalah baik. Hal ini terbukti dengan dapat berjalannya program sesuai dengan harapan dan keberhasilan mendapatkan orderan pertama pada media pemasaran yang ditawarkan kepada mitra. Dengan marketplace (Shopee) ini pemasaran PotAntik Sido Mulyo menjadi lebih mudah, efektif dan efisien serta dapat menjangkau pasar yang lebih luas tanpa mengenal jarak dan waktu.

\section{UCAPAN TERIMA KASIH}

Ucapan Terima Kasih juga sampaikan kepada mitra pengabdian dan semua pihak yang telah membantu terlaksanaanya pengabdian ini antara lain: Pimpinan Pot Antik SidoMulyo, PPKKN Unisnu Jepara, Lurah Desa Bapangan, dan Chief Editor Jurnal Pengabdian 
Masyarakat UNISSULA Semarang.

\section{DAFTAR PUSTAKA}

Firmansyah, A. (2019). Pemasaran Produk dan Merek. CV. Penerbit Qiara Media.

https://id.m.wikipedia.org/wiki/Shopee (Diakses pada 14/03/2021 pada pukul 11.34)

Rahmawati (2016). Manajemen Pemasaran. Mulawarman University PRESS.

Rosmadi, M. L. N. (2021). Penerapan Strategi Bisnis di Masa Pandemi Covid-19. IKRA-ITH EKONOMIKA, 4(1), 122-127.

Siswanto, T. (2013). Optimalisasi Sosial Media sebagai Media Pemasaran Usaha Kecil Menengah. Jurnal Liquidity, 2 (1).

Suci, Y. R. (2017). Perkembangan UMKM (Usaha Mikro Kecil dan Menengah) di Indonesia. Jurnal Cano Ekonomos, 6(1), 51-58.

Suswanto, P., \& Setiawati, S. D. (2020). Strategi Komunikasi Pemasaran Shopee Dalam Membangun Positioning di Tengah Pandemi Covid-19 Di Indonesia. LINIMASA: Jurnal Ilmu Komunikasi, 3(2), 16-29.

Wahidah, I., Athallah, R., Hartono, N. F. S., Rafqie, M. C. A., \& Septiadi, M. A. (2020). Pandemik COVID-19: Analisis Perencanaan Pemerintah dan Masyarakat dalam Berbagai Upaya Pencegahan. Jurnal Manajemen dan Organisasi, 11(3), 179-188.

Yustiani, R., \& Yunanto, R. (2017). Peran Marketplace Sebagai Alternatif Bisnis di Era Teknologi Informasi. Jurnal Ilmiah Komputer dan Informatika (KOMPUTA), 6(2). 